\title{
96. The Inflammability of Alkyl Halides and Their Influence on the Limit of Inflammability of Ethyl Ether-Air and Hydrocarbon-Air Mixtures.
}

\author{
By Yûzaburô NagaI.
}

Department of Applied Chemistry, Faculty of Engineering, Tokyo Imperial University.

(Rec. June 12, 1926. Comm. by Kuniichi Tawara, M.I.A., June 12, 1926.)

'The author determined the limits of inflammability in a glass tube of $5 \mathrm{~cm}$. in diameter and $65 \mathrm{~cm}$. long, in which the inflammable mixtures were ignited from the top by electric spark, both ends of the tube being opened before the ignition.

The results are shown in the following tables:-

TABre I. The influence of ethyl chloride on the lower limits of inflammability of ethyl ether and methyl cyclohexane.

\begin{tabular}{|c|c|c|}
\hline $\begin{array}{l}\text { Mole per cent. of ethyl } \\
\text { chloride in lower } \\
\text { limit mixtures. }\end{array}$ & $\begin{array}{l}\text { Mole per cent. of ethyl ether } \\
\text { or methyl cyclohexane in } \\
\text { lower limit mixtures. }\end{array}$ & $\begin{array}{l}\text { Constant of Le } \\
\text { Chatelier's rule. }\end{array}$ \\
\hline 0 & Ethyl ether, . & - \\
\hline 0.177 & 1.832 & 0.994 \\
\hline 0 & Methyl cyclohexane, 1.15 & - \\
\hline 0.502 & 1.007 & 1.004 \\
\hline
\end{tabular}

TABLE II. The influence of ethyl bromide on the limits of inflammability of ethyl ether.

\begin{tabular}{c|c|c}
\hline \multirow{2}{*}{$\begin{array}{c}\text { Mole per cent. of ethyl bromide } \\
\text { in limit mixtures. }\end{array}$} & \multicolumn{2}{|c}{$\begin{array}{c}\text { Mole per cent. of ethyl ether } \\
\text { in limit mixtures. }\end{array}$} \\
\cline { 2 - 3 } & Lower limit & Upper limit \\
\hline 0 & 1.93 & 6.66 \\
1.00 & - & 5.34 \\
1.50 & 1.81 & - \\
2.00 & - & 4.30 \\
3.00 & 1.37 & 3.37 \\
4.00 & 1.28 & 2.36 \\
4.50 & 1.27 & 1.87 \\
\hline
\end{tabular}


TABLE III. The influence of ethyl bromide on the limits of inflammability of hydrocarbon. ${ }^{\text {) }}$

\begin{tabular}{c|c|c}
\hline $\begin{array}{c}\text { Mole per cent. of ethyl bromide } \\
\text { in limit mixtures. }\end{array}$ & \multicolumn{2}{|c}{$\begin{array}{c}\text { Mole per cent. of hydrocarbon } \\
\text { in limit mixtures. }\end{array}$} \\
\cline { 2 - 3 } & Lower limit & Upper limit \\
\hline 0 & 1.14 & 4.00 \\
1.00 & 1.09 & 3.26 \\
2.00 & 0.93 & 2.65 \\
3.00 & 0.80 & 2.12 \\
4.00 & 0.72 & 1.58 \\
5.00 & 0.92 & 0.99 \\
\hline
\end{tabular}

TABLE IV. The influence of methyl iodide on the lower limit of ethyl ether.

\begin{tabular}{c|c}
\hline $\begin{array}{c}\text { Mole per cent. of methyl iodide } \\
\text { in lower limit mixture. }\end{array}$ & $\begin{array}{c}\text { Mole per cent. of ethyl ether in } \\
\text { lower limit mixtare. }\end{array}$ \\
\hline 0 & 1.93 \\
0.75 & 2.03 \\
\hline
\end{tabular}

The results listed in Tables II and III are shown diagrammatically in the accompanying Figures I and II respectively.

The lower limit of inflammability of ethyl chloride in air is $3.95 \%$ and its theoretical flame propagation temperature is therefore $1420^{\circ} \mathrm{C}$., which is nearly equal to those of ethyl ether and saturated hydrocarbons. The mixtures of ethyl etber (or methyl cyclohexane) and ethyl chloride obey strictly Le Chatelier's rule for the lower limit.

These normal inflammability can not be observed in the cases of ethyl bromide and methyl and ethyl iodides, for their vapours fail to propagate flame even when mixed with air at any ratio.") This remarkable difference between the inflammabilities of alkyl halides is parallel to that between the degrees of ionization of their vapours caused by $\mathrm{X}$ ray. According to the author, the non-inflammation of the alkyl bromide and iodides is due to the ionization of these vapours in flame; in other words, colliding with various flame molecules, a part of the halide molecules become of successively higher quantum states in expense of energy of the former, until finally ionization takes place.

1) A mixture of about $60 \%$ of iso-heptane and $40^{n}$ i of dimethyl cyclohexane.

2) W. A. White took a notice of non-inflammability of ethyl bromide (J. Chem. Soc., 1263, 1922). 
Thus the rate of activation of the halide molecules and the number of activated molecules, which are necessary for the combustion to take place, are suppressed markedly and consequently flame fails to propagate in the mixtures of air and the vapour of the bromide or iodides.

The author proved the above explanation by his experiments, showing that the electric conductivity of flame of the hydrocarbon is increased very much by the addition of ethyl bromide vapour, but is little influenced by the vapour of ethyl chloride, as listed in the following table:

\begin{tabular}{|c|c|c|c|c|c|}
\hline \multirow{2}{*}{$\begin{array}{l}\text { Alkyl halide } \\
\text { added. }\end{array}$} & \multicolumn{3}{|c|}{$\begin{array}{l}\text { Composition of mixed } \\
\text { gas, in which flame } \\
\text { propagated. }\end{array}$} & \multirow{2}{*}{$\begin{array}{l}\text { Voltage applied } \\
\text { to electrodes, } \\
\text { in volts. }\end{array}$} & \multirow{2}{*}{$\begin{array}{l}\text { Readings of } \\
\text { galvanometer } \\
\text { in } \mathrm{cm} .\end{array}$} \\
\hline & $\begin{array}{l}\text { Alkyl } \\
\text { halide }\end{array}$ & $\begin{array}{l}\text { hydro- } \\
\text { carbon }\end{array}$ & air & & \\
\hline Ethyl bromide & 4.00 & 0.81 & 95.19 & 2 & 5 \\
\hline " & $"$ & , & , & 4 & 10 \\
\hline & 0 & 1.20 & 98.80 & 4 & 0 \\
\hline Ethyl chloride & 4.8 & 2.0 & 93.2 & 4 & 0.4 \\
\hline$"$ & 2.3 & 0.7 & 97.0 & 4 & 0.2 \\
\hline
\end{tabular}

Fig. 1.

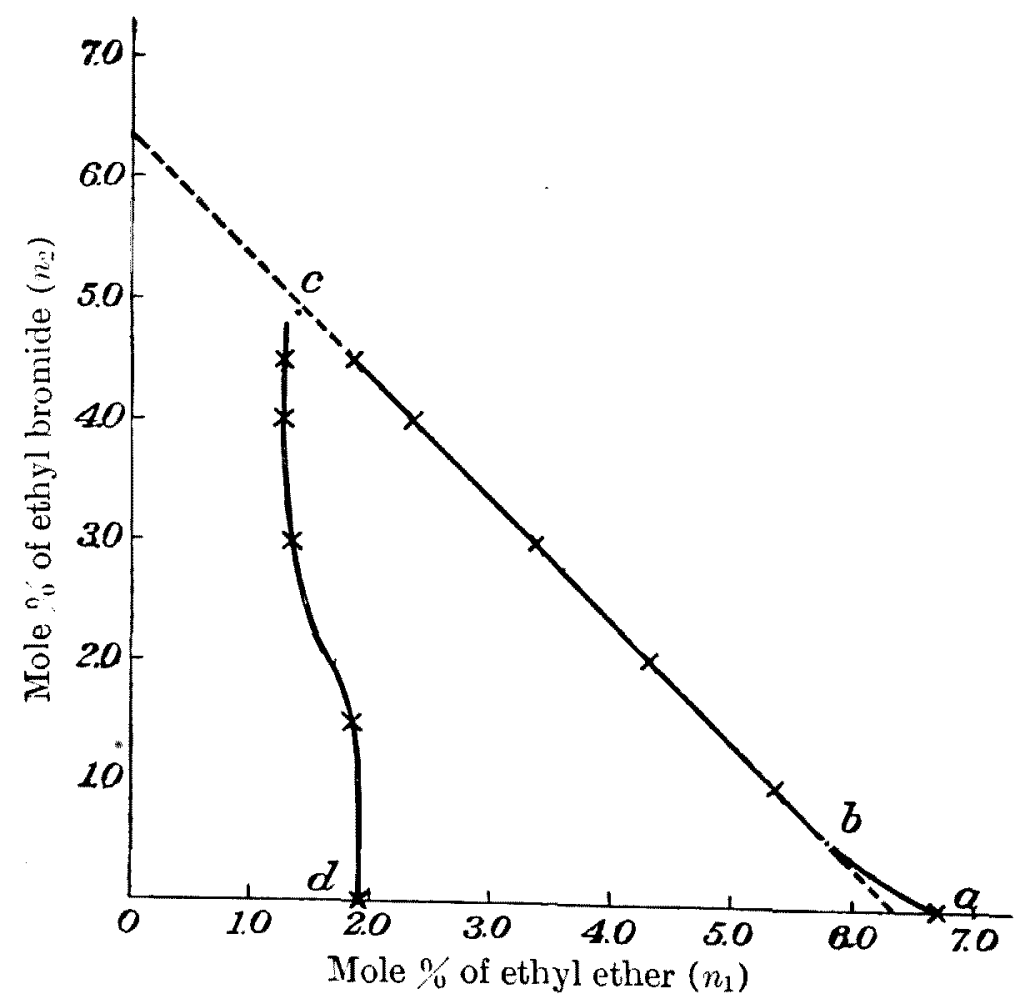


The ionization of ethyl bromide in flame, according to the theoretical consideration of the author, is not due to the high temperature of the flame, but is caused by the energy of the flame molecules as above described.

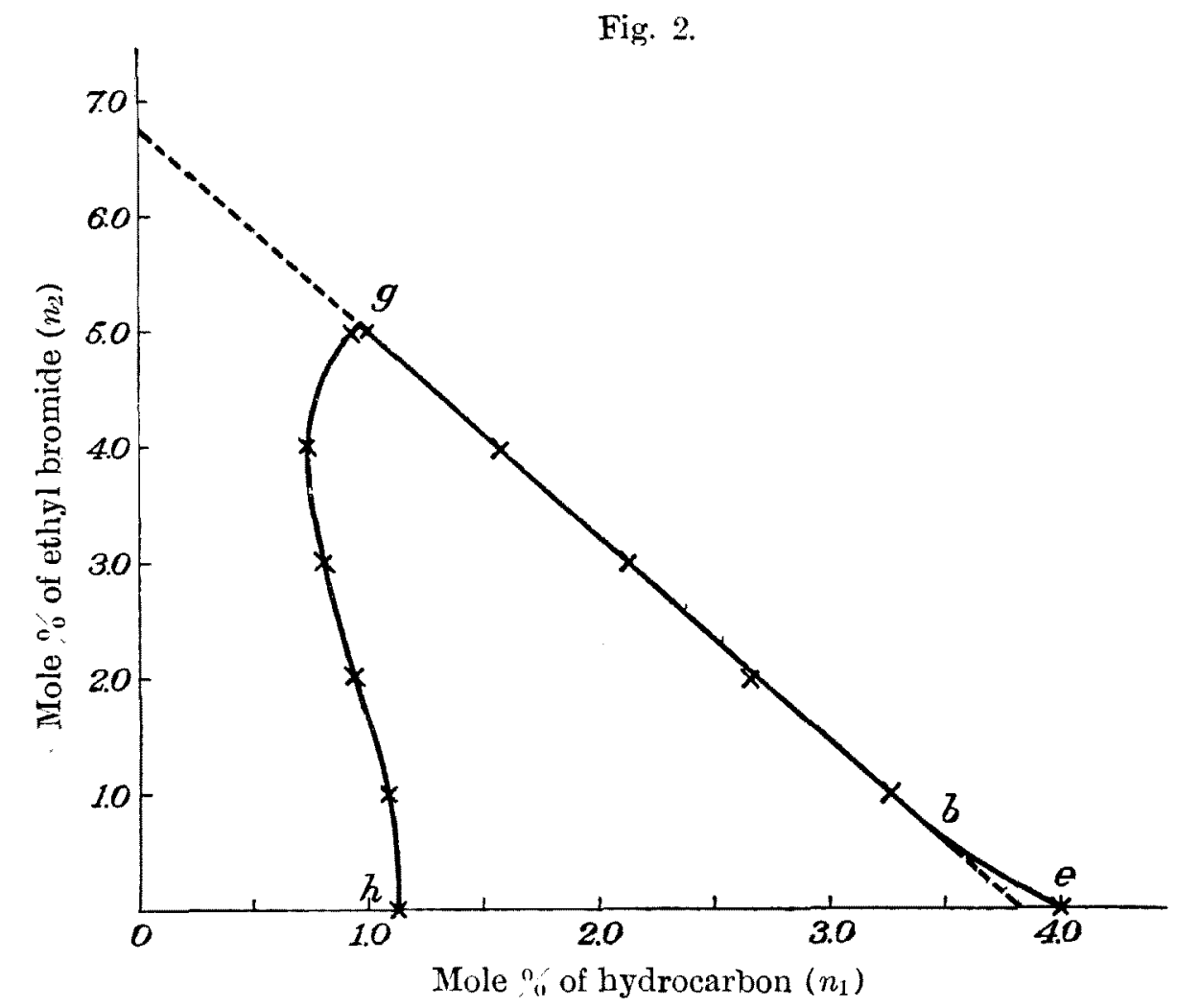

The upper limits of inflammability of ethyl ether and hydrocarbon, as shown in Tables II and III, are lowered rapidly by the addition of small amount of ethyl bromide up to the content of about one per cent of the latter, beyond which more slowly along straight lines $c d$ and $f g$ (Fig. I and II), whose equations are

$$
\begin{array}{ll}
\frac{n_{1}}{6.35}+\frac{n_{2}}{6.35}=1 & \text { (for straight line } c d \text { ) } \\
\frac{n_{1}}{3.85}+\frac{n_{2}}{6.80}=1 & \text { (for straight line } f g \text { ) }
\end{array}
$$

This mode of lowering of the upper limit can be explained when the effective ignition temperature (White, loc. cit.) of ethyl bromide in flame of ethyl ether or the hydrocarbon is assumed to be higher than those of ether and the hydrocarbon, for below its effective ignition temperature, ethyl bromide absorbs energy from the flame molecules, causing the decrease of the number of active molecules, which on collid- 
ing with oxygen begine to burn, and consequently making the flame temperature necessary for the propagation of flame raised higher up to its own effective ignition temperature. When this temperature is reached, ethyl bromide behaves as a normal combustible in flame of ether and the hydrocarbon and consequently the straight line relation above mentioned or Le Chatelier's rule is closely followed by these mixtures richer in the bromide.

The lower limits of ethyl ether and the hydrocarbon are little influenced by the addition of ethyl bromide up to the content of about one per cent of the latter, beyond which, however, they lower more rapidly. These will be easily explained in the same manner as in the case of the upper limits. Addition of ethyl bromide more than about three per cent, again influences very slightly the lower limit of ether. From this it may be seen that the combustion of ethyl bromide becomes difficult when the amount of other combustibles burning with it decreases below a certain limit. 